\title{
Emotional Intelligence and Its Relationship with English Teaching Effectiveness
}

\author{
Ebrahim Khodadady \\ Ferdowsi University of Mashhad, Iran \\ Email: ekhodadady@gmail.com
}

\begin{abstract}
This paper studied the responses of 1704 learners of English as a foreign language (EFL) to the Persian Characteristics of Effective English Language Teachers (CEELT) questionnaire and their 95 teachers' self report on Persian Emotional Quotient Inventory (EQ-I) in order to replicate Ghanizadeh and Moafian's (2009) study with a more homogeneous sample. In contrast to the significant and positive correlation found between teacher effectiveness as measured by the CEELT and emotional intelligence as measured by the EQ-I $(\mathrm{r}=.39, p<.05)$ in their study, a significant but negative relationship was found between the two measures in this study $(r=-.05, p<.05)$. However, the findings of this study showed that among the five competencies comprising the EQ-I, i.e., Intrapersonal, Interpersonal, Stress Management, Adaptability, and General Mood, only Interpersonal relates significantly not only to teacher effectiveness but also to its five underlying factors, i.e., Rapport, Fairness, Qualification, Facilitation and Examination as does its Empathy component. Similarly, out of the remaining 14 components, Social Responsibility of Interpersonal competence correlates positively and significantly with the CEELT and its Rapport, Fairness and Examination factors. The implications of the study are discussed and suggestions are made for future research.
\end{abstract}

Index Terms - teacher effectiveness, emotional intelligence, factors, competencies, components

\section{INTRODUCTION}

Learning English as a foreign language (EFL) requires formal education because it cannot be acquired naturally in a context such as Iran where no one speaks it either for communicative or for educational purposes. However, English is spoken as a second language in countries such as India to fulfill both functions. This very distinctive feature not only questions the position of scholars such as Yule (2006) who employ the expression "second language learning" (p. 163) interchangeably with EFL learning but also puts a largely neglected variable in language education, i.e., EFL teachers, into spotlight.

Moafian and Pishghadam (2008) were among the first researchers who developed a questionnaire to study teacher characteristics. By adding eight characteristics to 39 selected from 14 studies by Suwandee (1995), they designed a 47 item questionnaire called VIZHEGIHAYEH MODARESSAN MOVAFAGH ZABAN ENGLISI (p. 127), i.e., characteristics of successful English language teachers. By administering the questionnaire to 250 Persian EFL learners in Mashhad, Iran, and utilizing Principle Axis Factoring (PAF) along with Varimax Rotation with Kaiser Normalization, Moafian and Pishghadam extracted twelve factors, i.e., Attention to all, Examination, Commitment, Learning boosters, Creating a sense of competence, Teaching boosters, Physical and emotional acceptance, Empathy, Class attendance, and Dynamism.

Birjandi and Bagherkazemi (2010) renamed Moafian and Pishghadam's (2008) questionnaire as the "Successful Iranian EFL Teacher Questionnaire (SIETQ)" (p. 135) and tried to explore its relationship with critical thinking. Similarly, Khodadady (2010) renamed it as Characteristics of Effective English Language Teachers (CEELT) and explored its factorial validity with a more homogenous sample. While Moafian and Pishghadam validated it with 250 young and adult EFL learners whose age ranged between 14 to 36 (mean = 17.07), Khodadady administered it to 1469 high school EFL learners aged $14(17.8 \%), 15(33.6 \%), 16(15.7 \%), 17(17.8 \%), 18(11.8 \%)$ and $19(3.2 \%)$ with a mean of 15.82 and standard deviation of 1.40. He extracted only five factors called Rapport, Fairness, Qualification, Facilitation and Examination. The extraction of five instead of twelve latent variables from the CEELT paved the way to explore the relationship not only between teacher effectiveness and emotional intelligence (EI) but also between factors that underlie these two educationally important constructs. The EI was chosen to be explored with the CEELT for two reasons. First, it has attracted attention from almost all fields of social sciences. Fernandez-Berrocal and Extremera (2006), for example, reviewed the first 15 years of EI history and declared that it has gained popularity because a large number of professionals have acknowledged its importance in their fields in general and its contribution to evaluative and formative tasks in particular (e.g., Caruso \& Salovey, 2004; Feldman-Barret \& Salovey, 2002). After reviewing 69 independent studies Van Rooy and Viswesvaran (2004) declared that the EI has become "one of the most topical areas in organizational research" (pp. 71-2)

Two basic models are generally followed to measure the EI, i.e., ability (Mayer \& Salovey, 1997, Brackett \& Salovey, 2006) and self-rating report (Bar-On 1997, 2006). The first forms the basis of Mayer-Salovey-Caruso 
Emotional Intelligence Test (Mayer, Salovey, \& Caruso, 2002; Mayer, Salovey, Caruso, \& Sitarenios, 2001; 2003) which assesses the perception and understanding of simple and complex emotions in people and artistic products, assimilating emotions in thinking and decision making and regulating one's and others' emotions to achieve desired goals. Van Rooy and Viswesvaran (2004) believed that the ability-based EI measures "are less susceptible to faking than other measures that are more transparent" (p. 72).

Eysenck (1975), however, reviewed the research dealing with emotion measurement and declared that it has been achieved through three parameters, i.e., physiologically by measuring heart rates, introspectively via self-report, and observationally through studying behaviours. He concluded that "the evidence suggests that verbal report, far from being a throwback to pre-behaviouristic days, is in many ways the preferred method of measuring and indexing states of emotional arousal'" (p. 441).

Instead of measuring the EI through abilities such as perceiving and understanding emotions, Bar-On (1997, 2006), therefore, designed his own EQ-I through which test takers could rate certain verbal reports as a measure of their own EI. In order to establish the EQ-I as a distinct measure of intelligence, Bar-On (1997) administered it along with the Wechsler Adult Intelligence Scale (WAIS) and found no significant relationship between them $(r=.12, n=40)$ and thus concluded that the EQ-i had divergent validity. Similarly, Derksen, Kramer, and Datzko (2002) could not find any significant relationship between the EQ-i and the General Adult Mental Ability Scale (GAMA). However, the EQ-I scales of stress and general mood were significantly but weakly related to GAMA $(\mathrm{r}=.10$ and $\mathrm{r}=.12$, respectively, $\mathrm{n}=$ 489).

The second reason for exploring the relationship between the EI and the CEELT was to replicate the study of Ghanizadeh and Moafian (2009) [henceforth G \&M] with a more homogenous sample. They administered the EQ-I along with their "Characteristics of successful EFL teachers" questionnaire, i.e., CEELT, to 826 EFL learners whose age ranged between 14 and $66(\mathrm{M}=22.15, \mathrm{SD}=5.73)$. Their educational level was as divergent as their age in that it "varied from high school to PhD" (p. 3). The participants of the present study were, however, high school students only whose age ranged between 14 and $19(\mathrm{M}=15.82, \mathrm{SD}=1.40)$. This study was conducted to find out whether the CEELT and the EQ-I would correlate significantly with each other as they did in G\&M's study, i.e., $r=.39, p<.05$. It also investigated whether the competencies and components of the EQ-I would correlate significantly with the factors underlying the CEELT.

\section{METHODOLOGY}

\section{A. Participants}

Two groups of people took part in the present study: English language learners and English language teachers

\section{English Language Learners}

The CEELT was administered to 1704, $682(40 \%)$ male and $1022(60 \%)$ female, high school students. They were majoring in general courses $(n=699,41 \%)$, accounting $(n=19,1.3 \%)$, computer, $(n=30,1.8 \%)$, experimental sciences $(n=346,20.3 \%)$, humanities $(n=219,12.9 \%)$, and mathematics $(n=391,22.8 \%)$ at grade $1(n=690,40.5 \%)$, grade $2(n=348,20.4 \%)$, grade $3(n=278,16.3 \%)$ and pre-university $(n=388,22.8 \%)$. Out of 1704 learners, 980 (57.5\%) were studying English at 21 public high schools in the sixth educational district of Mashhad, the capital of Khorasan-e-Razavi province, Iran. The rest, i.e., 724 (42.5\%), studied English at beginning, intermediate and advanced English language proficiency levels at four private language institutes in the same city. The learners' age ranged between 14 and 19 (Mean = 15.84, SD =1.39). They conversed in Persian as their mother language.

\section{English Language Teachers}

Ninety five teachers of English in public high schools $(\mathrm{n}=47,49.5 \%)$ and private language institutes $(\mathrm{n}=48,50.5 \%)$ participated in the study voluntarily. Sixty seven $(70.5 \%)$ were female and $28(29.5 \%)$ were male in gender. Their age ranged between 20 and 52 (Mean $=33.92, \mathrm{SD}=7.52)$. The teachers held $\mathrm{BA} / \mathrm{BSc}(\mathrm{n}=74,77.9 \%)$ and MA/MSc $(\mathrm{n}=21$, $22.1 \%)$ in applied mathematics $(\mathrm{n}=1,1.1 \%)$, arts $(\mathrm{n}=1,1.1 \%)$, engineering $(3,3.3 \%)$, English language and literature $(\mathrm{n}=38,40.0 \%)$, English translation $(\mathrm{n}=8,8.4 \%)$, linguistics $(\mathrm{n}=10,10.5 \%)$ and teaching English as a foreign language $(\mathrm{n}=34,35.8 \%)$. The teachers all spoke Persian as their mother language.

\section{B. Instruments}

Two instruments were used in the present study, i.e., Characteristics of Effective English Language Teachers (CEELT) and BarOn Emotional Quotient Inventory (EQ-I).

\section{CEELT}

The Persian CEELT comprised two parts. The first raised five multiple choice and short-answer questions related to participants' gender, age, English language achievement, field and year of study. The second, however, called for reading the 47 statements and indicating whether the participants' English teachers possessed the specified characteristics and exhibited certain behaviours in the class on the basis of a five-point Likert scale, i.e., completely agree, agree, to some extent agree, disagree, and completely disagree. The scores of 5, 4, 3,2 and 1, were assigned to these points, respectively. Both sections of the CEELT were presented in Persian in this study to avoid possible misunderstandings on the part of English language learners. (The English version of the CEELT is given as Appendix $1)$. 
Table 1 presents the descriptive statistics of the CEELT and its underlying latent variables extracted by Khodadady (2010) with PAF and rotated via Varimax with Kaiser Normalization. As can be seen, the CEELT enjoys an excellent reliability level, i.e., $\alpha=.97$. Among its five factors, Fairness and Qualification are the most reliable, i.e., $\alpha=.92$ and .90, respectively. The lowest reliability coefficient belongs to Examination, i.e., $\alpha=.72$. However, considering the fact that all acceptably cross loading items have been removed from the factors and Examination comprises only two characteristics, this level of reliability sounds acceptable.

TABLE 1.

THE DESCRIPTIVE STATISTICS OF CEELT AND ITS FIVE FACTORS

\begin{tabular}{|c|c|c|c|c|c|}
\hline Factors & \# of item & Loading Characteristics & Eigenvalue & Variance explained & Alpha \\
\hline Rapport & 7 & $3,4,5,7,8,9,24$ & 5.961 & $12.1 \%$ & .83 \\
\hline Fairness & 15 & $25,33,34,35,36,38,39,40,41,42,43,44,45,46,47$ & 5.499 & $11.5 \%$ & .92 \\
\hline Qualification & 14 & $1,2,6,12,13,14,21,22,23,28,29,30,31,32$ & 4.910 & $11.2 \%$ & .90 \\
\hline Facilitation & 9 & $10,11,15,16,17,18,26,27,37$ & 4.020 & $9.6 \%$ & .85 \\
\hline Examination & 2 & 19,20 & 1.964 & $4.2 \%$ & .72 \\
\hline CEELT & 47 & & - & $48.6 \%$ & \begin{tabular}{|l|}
.97 \\
\end{tabular} \\
\hline
\end{tabular}

\section{2. $E Q-I$}

The EQ-I developed by Bar-On (1996) and translated into Persian by Dehshiry (2003) was employed in this study. It consists of 133 positively or negatively-keyed items presented on a Likert Scale of five points. The EFL teachers were required to decide whether each statement was 1) very seldom, 2) seldom, 3) sometimes, 4) often, or 5) very often true of them or not true of them. A value of 0 was also assigned to any statement whose application to the respondents was not specified.

The self-report EQ-I measures five broad areas of skills or competencies and 15 factorial components, i.e., intrapersonal intelligence (emotional self-awareness, assertiveness, self-regard, self-actualization, independence); interpersonal intelligence (empathy, interpersonal relationships, social responsibility); adaptability (problem solving, reality testing, flexibility); stress management (stress tolerance, impulse control); and general mood (happiness, optimism). Higher scores indicate a higher level of emotional intelligence (Bar-On, 1997, 2003). Fahim and Pishghadam (2007) administered the Persian version of the EQ-I to 508 university students of English and reported an alpha reliability coefficient of .86. They did not, however, report any reliability estimates for the competencies measured by the EQ-I.

\section{Procedure}

After securing the approval of English language teachers and learners and setting a certain date for the administration of questionnaires, the researcher attended the classes in person and had the learners take the CEELT while their teacher completed the EQ-I. All the directions were given in Persian and both the learners and teachers were encouraged to raise questions if they faced any problems understanding any statement. The participants were asked not to write their names so that their identity remained anonymous. Some teachers, however, showed interest in the EQ-I and asked the researcher to provide them with the results whenever available. Upon scoring the test these teachers were contacted either in person or on phone and their scores was reported.

\section{Data Analysis}

The reliability of the CEELT and EQ-I was estimated by employing Cronbach Alpha. The relationships among the factors underlying the CEELT and the competencies measured by the EQ-I were explored via Bivariate Pearson Correlation coefficients. In determining the descriptive statistics of the CEELT and correlating its five underlying factors with each other, the highest acceptable loading of a cross loading characteristic on a given factor was accepted arbitrarily as its main contribution to that particular factor and its acceptable cross loadings on other factors were removed. All the statistical analyses were conducted by utilizing IBM SPSS Statistics 19.0 to test the following five research hypotheses.

H1. The magnitude of significant correlation found between the CEELT and the EQ-I will be similar to the one reported by G\&M.

H2. The CEELT will correlate significantly with the five competencies of the EQ-I.

H3. The five factors underlying the CEELT will correlate significantly with the five competencies of the EQ-I.

H4. The CEELT will correlate significantly with the fifteen components of the EQ-I.

H5. The five factors underlying the CEELT will correlate significantly with the fifteen components of the EQ-I.

\section{RESULTS AND DISCUSSIONS}

Table 2 presents the descriptive statistics, reliability and correlation coefficients of factors underlying the CEELT. (The descriptive statistics of the answers given to 47 items comprising the CEELT and the rounded percentage of five points chosen by 1704 EFL learners are given in appendix 2.) As can be seen, the CEELT is a highly reliable measure of teacher effectiveness, i.e., $\alpha=.97$. The alpha of its lowest reliable factor (.72), i.e., Examination, is noticeably higher that the lowest reliable competence on the EQ-i, i.e., Interpersonal $(\alpha=.62)$. The difference becomes more outstanding 
when it is pointed out that Examination consists of only two items whereas Interpersonal comprises 24. Examination also shows the lowest significant relationships not only with the CEELT $(\mathrm{r}=.58, p<.01)$ itself but also with other four factors, i.e. Rapport $(\mathrm{r}=.41, p<.01)$, Fairness $(\mathrm{r}=.50, p<.01)$, Qualification $(\mathrm{r}=.49, p<.01)$, and Facilitation $(\mathrm{r}$ $=.52, p<.01)$.

TABLE 2.

DESCRIPTIVE STATISTICS, RELIABILITY AND CORRELATION COEFFICIENTS OF FACTORS UNDERLYING THE CEELT

\begin{tabular}{|c|c|c|c|c|c|c|c|c|c|c|}
\hline & \# of items & Mean & SD & Alpha & 1 & 2 & 3 & 4 & 5 & 6 \\
\hline 1 Rapport & 7 & 28.22 & 6.722 & .83 & 1 & $.77^{*}$ & $.76^{*}$ & $.73^{*}$ & $.41^{*}$ & $.87^{*}$ \\
\hline 2 Fairness & 15 & 60.47 & 12.898 & .92 & $.77^{*}$ & 1 & $.83^{*}$ & $.80^{*}$ & $.50^{*}$ & $.95^{*}$ \\
\hline 3 Qualification & 14 & 60.37 & 9.666 & .90 & $.76^{*}$ & $.83^{*}$ & 1 & $.78^{*}$ & $.49^{*}$ & $.92^{*}$ \\
\hline 4 Facilitation & 9 & 31.56 & 8.344 & .85 & $.73^{*}$ & $.80^{*}$ & $.78^{*}$ & 1 & $.52^{*}$ & $.90^{*}$ \\
\hline 5 Examination & 2 & 7.27 & 2.532 & .72 & $.41^{*}$ & $.50^{*}$ & $.49^{*}$ & $.52^{*}$ & 1 & $.58^{*}$ \\
\hline 6 CEELT & 47 & 187.90 & 35.932 & .97 & $.87^{*}$ & $.95^{*}$ & $.92^{*}$ & $.90^{*}$ & $.58^{*}$ & 1 \\
\hline
\end{tabular}

Table 3 presents the descriptive statistics, reliability and correlation coefficients obtained among the five competencies of the EQ-I. It must be noted that out of 133 items comprising the EQ-i, fifteen, i.e., 5, 12, 25, 34, 41, 50, $57,65,71,79,94,101,109,115$, and 123 have been inserted by their designer to secure positive impression, negative impression and response validity only. The final item, i.e., 133, is also a self-report on honesty of responding and is included neither in its five competencies nor in its fifteen components. (The descriptive statistics of the answers given to 56 positive and 61 reverse items comprising the EQ-I and the rounded percentage of five points chosen by 95 EFL teachers are given in Appendix 3.)

TABLE 3.

DESCRIPTIVE STATISTICS, RELIABILITY AND CORRELATION COEFFICIENTS OF COMPETENCIES UNDERLYING THE EQ-I

\begin{tabular}{|c|c|c|c|c|c|c|c|c|c|c|}
\hline EQ-i and its Scales & \# of items & Mean & SD & Alpha & 1 & 2 & 3 & 4 & 5 & 6 \\
\hline 1 Intra-personal & 40 & 151.65 & 18.2 & .91 & 1 & $.42^{*}$ & $.59^{*}$ & $.73^{*}$ & $.71^{*}$ & .89 \\
\hline 2 Inter-personal & 24 & 115.97 & 12.5 & .63 & $.42^{*}$ & 1 & $.28^{*}$ & $.44^{*}$ & $.45^{*}$ & $.62^{*}$ \\
\hline 3 Stress Management & 18 & 63.76 & 9.9 & .88 & $.59^{*}$ & $.28^{*}$ & 1 & $.69^{*}$ & $.61^{*}$ & $.78^{*}$ \\
\hline 4 Adaptability & 26 & 98.16 & 12.1 & .88 & $.73^{*}$ & $.44^{*}$ & $.69^{*}$ & 1 & $.71^{*}$ & $.90^{*}$ \\
\hline 5 General Mood & 17 & 68.91 & 7.7 & .83 & $.71^{*}$ & $.45^{*}$ & $.61^{*}$ & $.71^{*}$ & 1 & $.83^{*}$ \\
\hline $6 \mathrm{EQ}-\mathrm{i}$ & 117 & 446.85 & 44.8 & .94 & $.89^{*}$ & $.62^{*}$ & $.78^{*}$ & $.90^{*}$ & $.83^{*}$ & 1 \\
\hline
\end{tabular}

As can be seen in Table 3, the 117-item EQ-I is highly reliable, i.e., $\alpha=.94$, as is its Intrapersonal competency, i.e., $\alpha=.91$. Among the five competencies, Interpersonal has the lowest reliability, i.e., $\alpha=.63$, which might be attributed to its three cross loading items, i.e., 23, 31, and 62, contributing to Intrapersonal and General Mood competencies as well. Similarly, Item 11 contributes to both Intrapersonal and General Mood, 20 to Stress Management and General Mood, $\mathbf{3 5}$ to Intrapersonal and Adaptability, $\mathbf{8 8}$ to Intrapersonal and Adaptability, 108 to Stress Management and General Mood, respectively, indicating that the five competencies comprise 125 items whereas the EQ-I itself consists of 117.

As it can also be seen in Table 3 above, in addition to the inter correlation coefficients among the EQ-I and its five subscales, their reliability and descriptive statistics are given in this study. They are also reported as the total score, the validity score and 15 components in the literature (see Hemmati, Mills, \& Kroner, 2004). However, G\&M have reported only the descriptive statistics of the EQ-I as shown in Table 4. As can be seen, G\&M did not specify how many items of the EQ-I they included in their descriptive, reliability and correlation analyses. However, it can be inferred from their result that they included all 133 items in their analysis otherwise more than half of their participants must have chosen often true of me having the value of 4 for all 117 items. If we multiply 117 by 4 , the result would be 468, which is lower than the reported mean by G\&M, i.e., 470.16, supporting the inference made in this study.

TABLE 4.

CONTRASTIVE DESCRIPTIVE STATISTICS OF THE EQ-I OBTAINED IN THIS STUDY (TS) AND G\&M

\begin{tabular}{|l|l|l|l|l|l|l|l|l|l|}
\hline \# of items & \multicolumn{2}{l|}{ Minimum } & \multicolumn{2}{l|}{ Maximum } & Mean & SD \\
\hline TS & G\&M & TS & G\&M & TS & G\&M & TS & G\&M & TS & G\&M \\
\hline 117 & - & 327 & 349 & 548 & 572 & 446.85 & 470.16 & 44.80 & 53.68 \\
\hline
\end{tabular}

It seems that G\&M have unknowingly included the positive impression (PI) scale, negative impression (NI) scale, and inconsistency index (II) in their correlational analysis of the data obtained on the EQ-I and CEELT. These scales and indices are inserted in the EQ-I to determine the validity of the individual scores. The PI is, for example, developed to

... detect dissimulation or the feigning of enhanced emotional functioning. When these scores are elevated, the respondent may have consciously attempted to give a positive impression or engage in self-deception, show lack of selfinsight, or possess an unwillingness to face his or her limitations. Sometimes a high PI score could also mean a need for social conformity, approval, self-protection, or avoidance of criticism (Butler \& Chinowsky, 2006, p. 121). 
Bar-On (2003) himself, for example, reported the performance of an individual on the EQ-I and concluded that "the validity indicators are all in the acceptable range suggesting valid responses and results that are not unduly influenced by response style" (p. 11). Bar-On (2002), however, questioned the performance of a group of five people on the EQ-I because of markedly high scores on the PI scale and announced that "the scores provided in this report may not accurately represent the emotional functioning of this group. Use additional sources of information to further analyze/verify these results (p. 22)" Since no interpretation of scores are usually intended in research projects some scholars like Batool (2009) and Batool and Khalid (2011) excluded validity items from their study. In the present study, these items have, nonetheless, been included in the inventory itself but excluded from statistical analysis.

The reliability coefficient obtained on the 117-item EQ-I in this study, i.e., $\alpha=.94$, is far greater than the coefficient obtained by G\&M, i.e., $\alpha=.80$, highlighting the fact that the administration of the same test to a relatively larger sample i.e., 95 vs. 89, and excluding its validity and honesty items increases its reliability. Although the inclusion of more items and making inventories like the EQ-I longer usually renders them more reliable, the coefficient reported by G\&M is noticeably lower.

Table 5 presents the correlation coefficient obtained among the EQ-I, CEELT and their competencies and factors. As can be seen, there is a negative but significant relationship between the CEELT and EQ-I $(\mathrm{r}=-.05, p<.05)$. This finding is in sharp contrast to that of G\&M $(\mathrm{r}=.39, p<.05)$ and thus disconfirms the first hypothesis that the magnitude of significant correlation found between the CEELT and the EQ-I will be similar to the one reported by G\&M. While this study shows that the EQ-I does not explain more than $0.25 \%$ of variance in the CEELT, it amounts to $15.2 \%$ in G\&M's study. Furthermore, the direction of relationship is different in the two studies. The correlation coefficient obtained in the present study shows that the more emotionally intelligent the EFL teachers are, the less effective they will be in their classes and thus contradicts G\&M's finding.

TABLE 5.

CORRELATIONS AMONG THE COMPETENCIES OF EQ-I AND FACTORS OF CEELT

\begin{tabular}{|c|c|c|c|c|c|c|c|}
\hline \multirow{2}{*}{$\begin{array}{l}\text { EQ-I and its five } \\
\text { competencies }\end{array}$} & \multicolumn{2}{|l|}{ CEELT } & \multicolumn{5}{|c|}{ CEELT factors } \\
\hline & This study & G\&M & Rapport & Fairness & Qualification & Facilitation & Examination \\
\hline EQ-i & $-.05^{*}$ & $.39 *$ & $-.07^{*}$ & $-.05^{*}$ & -.01 & $-.09^{* *}$ & .04 \\
\hline Intrapersonal & .00 & - & -.04 & .00 & $.06^{*}$ & -.03 & .05 \\
\hline Interpersonal & $.07^{* *}$ & - & $.08^{* *}$ & $.07^{* * *}$ & $.08^{* * 6}$ & .01 & $.10^{* *}$ \\
\hline Stress Management & $-.16^{* *}$ & - & $-.18^{* *}$ & $-.14^{* * *}$ & $-.14^{* *}$ & $-.16^{* *}$ & $-.06^{*}$ \\
\hline Adaptability & $-.11^{* *}$ & - & $-.12^{* *}$ & $-.10^{* *}$ & $-.07^{\text {** }}$ & $-.13^{* *}$ & .01 \\
\hline General Mood & -.03 & - & -.03 & -.03 & -.00 & -.04 & .02 \\
\hline
\end{tabular}

The results obtained in this study, however, show that there is a positive and significant relationship between the Interpersonal competence of EI and the CEELT $(\mathrm{r}=.07, p<.01)$. Similar to the EQ-I, however, its Stress Management ( $\mathrm{r}=-.16, p<.01)$ and Adaptability $(\mathrm{r}=-.11, p<.01)$ competencies correlate significantly but negatively with the CEELT. Although these findings provide $60 \%$ of confirmation for the second hypothesis and shows that the CEELT correlates significantly with three competencies of the EQ-I, only Interpersonal (20\%) correlates positively with the CEELT. The amount of variance in the CEELT which is explained by this competency, i.e., 0.49, is almost twice the variance explained by the EQ-I itself, i.e., 0.25.

Among the five competencies of the EQ-I, the Interpersonal correlates positively and significantly with the Rapport $(\mathrm{r}=.08, p<.01)$, Fairness $(\mathrm{r}=.07, p<.01)$, Qualification $(\mathrm{r}=.08, p<.01)$, and Examination $(\mathrm{r}=.10, p<.01)$ factors underlying the CEELT. As the second scale of the EI, the Intrapersonal competency correlates positively and significantly only with one factor, i.e., Qualification $(\mathrm{r}=.06, p<.05)$. These results largely disconfirm the third hypothesis that the five factors underlying the CEELT will correlate significantly with the five competencies of the EQ-I.

As can be seen in Table 4, the highest positive relationship obtained between the EI competencies and CEELT factors is between Interpersonal and Examination, indicating that the more interpersonally intelligent the EFL teachers are, the more favorably their learners rate their examination activities. This finding is, however, in sharp contrast to what Khodadady and Mirjalili (2012) found in their administration of the CEELT and the NEO-FFI to 1260 EFL learners and their 118 teachers. They found a negatively significant correlation between the Extroversion dimension of teacher personality and Examination $(\mathrm{r}=-.07, p<.05)$, requiring a closer examination of components comprising the Interpersonal competency of the EQ-I.

Table 6 presents the correlation coefficients (CCs) obtained among the fifteen EQ-I components and the CEELT as well as its five factors. As can be seen, the CEELT correlates positively and significantly only with two components, i.e., Empathy $(\mathrm{r}=.11, p<.01)$ and Social Responsibility $(\mathrm{r}=.05, p<.05)$. These results disconfirm the fourth hypothesis that The CEELT will correlate significantly with the fifteen components of the EQ-I. 
TABLE 6.

CORRELATIONS AMONG THE COMPONENTS OF THE EQ-I AND RAPPORT (R), FAIRNESS (FAIR), QUALIFICATION (Q), FACILITATION (F) AND EXAMINATION (E) FACTORS COMPRISING THE CEELT

\begin{tabular}{|c|c|c|c|c|c|c|c|}
\hline Competencies & Components & CEELT & $\mathbf{R}$ & Fair & $\mathbf{Q}$ & $\mathbf{F}$ & $\mathbf{E}$ \\
\hline \multirow{5}{*}{ Intrapersonal } & Self-Regard & -.00 & -.03 & -.01 & .03 & -.03 & $.05^{*}$ \\
\hline & Emotional Self-Awareness & .04 & .01 & .03 & $.06^{* *}$ & .01 & $.08^{* *}$ \\
\hline & Assertiveness & -.01 & $-.05^{*}$ & -.03 & $.06^{*}$ & -.03 & .04 \\
\hline & Independence & -.03 & $-.06^{*}$ & -.02 & .02 & $-.05^{*}$ & -.01 \\
\hline & Self-Actualization & .02 & -.02 & .03 & $.06^{*}$ & -.01 & .03 \\
\hline \multirow{3}{*}{ Interpersonal } & Empathy & $.11^{* *}$ & $.10^{* *}$ & $.11^{* *}$ & $.10^{* *}$ & $.05^{*}$ & $.08^{* *}$ \\
\hline & Social Responsibility & $.05^{*}$ & $.06^{* * 2}$ & $.05^{*}$ & .05 & -.01 & $.12^{* *}$ \\
\hline & Interpersonal Relationships & .04 & .04 & .02 & $.07^{* *}$ & .00 & .05 \\
\hline \multirow{2}{*}{ Stress Management } & Stress Tolerance & $-.19^{* *}$ & $-.21^{* * *}$ & $-.18^{* * *}$ & $-.14^{* *}$ & $-.16^{* *}$ & $-.10^{* *}$ \\
\hline & Impulse Control & $-.11^{* *}$ & $-.12^{* *}$ & $-.08^{* *}$ & $-.10^{* *}$ & $-.12^{* *}$ & -.01 \\
\hline \multirow{3}{*}{ Adaptability } & Reality Testing & .014 & -.02 & .01 & .03 & .01 & $.06^{*}$ \\
\hline & Flexibility & $-.16^{* *}$ & $-.16^{* *}$ & $-.14^{* *}$ & $-.12^{* *}$ & $-.19^{* *}$ & -.04 \\
\hline & Problem Solving & $-.13^{* *}$ & $-.13^{* *}$ & $-.12^{* *}$ & $-.09^{* *}$ & $-.16^{* *}$ & -.00 \\
\hline \multirow{2}{*}{ General Mood } & Optimism & .01 & -.02 & .01 & .04 & -.01 & .04 \\
\hline & Happiness & $-.05^{*}$ & -.03 & $-.05^{*}$ & -.04 & $-.06^{*}$ & .00 \\
\hline
\end{tabular}

Among the 15 components, Stress Tolerance shows the highest significant but negative correlation with the CEELT $(\mathrm{r}=-.19, p<.01)$. Furthermore, it correlates negatively and significantly with Rapport $(\mathrm{r}=-.21, p<.01)$, Fairness, $(\mathrm{r}=$ $-.18, p<.01)$, Qualification, $(\mathrm{r}=-.14, p<.01)$, Facilitation $(\mathrm{r}=-.16, p<.01)$, and Examination $(\mathrm{r}=-.10, p<.01)$, indicating that the more stress tolerant the EFL teachers are, the less effective in general and the less communicative, fair, qualified, facilitative and evaluative they will be in particular in their teaching! Similar negative but significant relationship was found between the other component of Stress Management competency of the EQ-I, i.e., Impulse Control, and the CEELT $(\mathrm{r}=-.11, p<.01)$ and its Rapport $(\mathrm{r}=-.12, p<.01)$, Fairness, $(\mathrm{r}=-.08, p<.01)$, Qualification, $(\mathrm{r}=-.10, p<.01)$, and Facilitation $(\mathrm{r}=-.12, p<.01)$ factors, indicating that more effective EFL teaching in Mashhad requires less Impulse Control.

The negative but significant relationship between Stress Management and EFL teacher effectiveness can be attributed to certain features unique to the job. For example, in response to the reverse item 27, i.e., when I start talking, it is hard to stop, $2(2.1 \%), 9(9.5 \%) .24(25.3 \%), 44(46.3 \%)$, and $16(16.8 \%)$ teachers accepted that it is very often, often, sometimes, seldom and very seldom true of them, respectively. Their responses might hold true as far as their personal life is concerned, however, the researcher's experience as an EFL teacher shows that most of the talking in EFL classes is done by the teacher.

As it can also be seen in Table 6, Empathy is the only component of the EQ-I which correlates positively and significantly with all the five factors underlying the CEELT, i.e., Rapport $(\mathrm{r}=.11, p<.01)$, Fairness $(\mathrm{r}=.10, p<.01)$, Qualification $(\mathrm{r}=.10, p<.01)$, Facilitation Qualification $(\mathrm{r}=.05, p<.05)$, and Examination $(\mathrm{r}=.08, p<.01)$. These results disconfirm the fifth hypothesis that the five factors underlying the CEELT will correlate significantly with the fifteen components of the EQ-I.

Among the three components comprising the Interpersonal competence of the EQ-I, it is Social Responsibility whose magnitude of correlation with the CEELT is the same as the EQ-I and CEELT but in a positive direction $(\mathrm{r}=.05, p$ $<.05)$. These results indicate that the EQ-I as a whole measures a trait whose constituting components reveal directionally opposite relationships with teacher effectiveness with the same degree of relationship or even higher. While out of 15 components of the EQ-I, two correlate positively with the CEELT, i.e., Social Responsibility ( $\mathrm{r}=.05, p$ $<.05)$ and Empathy $(\mathrm{r}=.11, p<.01)$, five correlate negatively, i.e., Happiness $(\mathrm{r}=-.05, p<.05)$, Impulse Control $(\mathrm{r}=-$ $.11, p<.01)$, Problem Solving $(\mathrm{r}=-.13, p<.01)$, Flexibility $(\mathrm{r}=-.16, p<.01)$, and Stress Tolerance $(\mathrm{r}=-.19, p<.01)$.

Similar to Reverse item 27, item 58, People tell me to lower my voice in discussions, provides another example which explains the negative but significant relationships found between Impulse Control, a component of Stress Management, and the CEELT. Three (3.2\%), 8 (8.4\%), 31 (32.6\%), 24 (25.3\%), and 29 (30.5\%) EFL teachers accepted that the statement is very often, often, sometimes, seldom and very seldom true of them, respectively. These results show that while $44.2 \%$ of EFL teachers do very often, often and sometimes, raise their voices in discussions with people in general, they have to do so most of the time, say $90 \%$ or even more, in order to have all learners hear them in oft-crowded EFL classes, hence a negative relationship between Impulse Control, the CEELT and its Rapport, Fairness, Qualification, and Facilitation factors.

\section{CONCLUSION}

By administering the two Persian CEELT and EQ-I questionnaires to 1704 EFL learners and 95 teachers of the same learners in Mashhad, Iran, the relationship between EFL teacher effectiveness and their emotional intelligence was explored in this study by replicating G\&M's study which had established a relatively strong and significant relationship between the two. The results of this study did not, however, support their finding in terms of the magnitude and 
direction of relationship. As two distinct measures employed in EFL learning and teaching, the CEELT and EQ-I do not reveal consistent relationships with each other in terms of their underlying constructs, competencies, components and factors.

As two constructs, the CEELT and EQ-I correlate significantly and negatively with each other and explain only a tiny amount of variance in each other, i.e., $0.25 \%$. Although this significant relationship is very low, it does show that the more emotionally intelligent the EFL teachers are, the less effective they will become in their teaching in Mashhad. This conclusion is, however, challenged because of the complexity involved in the structure of the EQ-I and the nature of its items.

Structurally, the EQ-I contains cross loading items which contribute not only to two different competencies but also to two different components. Item 11, I feel sure of myself in most situations, is, for example, a part of General Mood and Intrapersonal competencies and their Optimism and Self-Regard components, respectively. It is, therefore, suggested that factorial studies be conducted on the Persian EQ-I with specific samples such as EFL teachers to find out whether items such as eleven would cross load on more than one factor. These cross loading items should have contributed to the degree and type of relationships found in this study.

Ontologically, the EQ-I contains validity items such as item 94, I have not broken a law of any kind, which have been designed to measure positive impressions. The inclusion of validity items seem to have resulted in obtaining high correlations between the CEELT and EQ-I such as the coefficient reported by G\&M. In addition to making the EQ-I too long, the contribution of these items to the assessment of EI is questionable, at least in research contexts where the respondents remain anonymous and thus their tendency to leave a positive impression on researchers becomes irrelevant if not meaningless. It is therefore suggested that the validity items be removed in future studies.

In addition to the construct measured by the EQ-I, its five competencies relate differently to teacher effectiveness. While Intrapersonal and General Mood do not relate significantly to the CEELT, the magnitude of significant correlations found between Interpersonal, Stress Management, and Adaptability competencies and the CEELT was higher than that of EQ-I and CEELT. However, among the three significantly correlating competencies, only Interpersonal shows positive relationship with the CEELT, indicating that the more interpersonally intelligent the EFL teachers are, the more effective they will be in their teachings.

The Interpersonal competency of the EQ-I also correlated positively and significantly with the Rapport, Fairness, Qualification and Examination factors of the CEELT. The Intrapersonal was the other competency which did the same with the Qualification factor of the CEELT only. These results indicate that the more interpersonally intelligent the EFL teachers are, the more effective they become in establishing rapport with their learners, implementing fairness, applying their qualification to teaching and including examination as an integral part of teaching. They also indicate the more qualified the EFL teachers are, the more intrapersonally intelligent they become.

Among the fifteen components comprising the five competencies, only those belonging to the Intrapersonal and Interpersonal competencies correlate positively and significantly with the five factors constituting the CEELT. While seven out of fifteen components comprising the EQ-I correlate significantly with the CEELT, five of these seven components show negative relationships with the CEELT, i.e., Impulse Control, Problem Solving, Flexibility, Stress Tolerance, and Happiness. Only Empathy and Social Responsibility correlate positively and significantly with the CEELT. The findings of this study thus challenge the assertion that the EI is "an array of emotional and social abilities, competencies and skills that enable individuals to cope with daily demands and be more effective in their personal and social life" (Bar-On, Tranel, Denburg, \& Bechara, 2003, p. 1790). They indicate that EFL teacher effectiveness as measured by the CEELT requires less Impulse Control, Problem Solving, Flexibility, Stress Tolerance, and Happiness unless they are measured by a different scale. It is therefore suggested that either the EQ-I and CEELT be modified or different measures of EFL teacher effectiveness and emotional intelligence be employed to explore the relationship.

\section{ACKNOWLEDGEMENTS}

Dr. Ali Shariati Faculty of Letters and Humanities at Ferdowsi University of Mashhad funded this study via grant coded 2/15545. The author wishes to acknowledge the support of its authorities and express his gratitude for their approval of the grant in session 167 on November 2, 2010.

\section{APPENDIX 1 CHARACTERISTICS OF EFFECTIVE ENGLISH LANGUAGE TEACHERS (CEELT)}

Directions: There are 47 statements in this questionnaire. Read each statement carefully and decide whether you completely agree (CA), agree (A), to some extent agree (SEA), disagree (D) and completely disagree (CD) with it. Remember, there is no right or wrong answer. Each statement simply reflects your views, feelings, and attitudes towards your English teachers. 


\begin{tabular}{|c|c|c|c|c|c|}
\hline My English teacher ... & $\mathrm{CD}$ & $\mathrm{D}$ & SEA & A & $\mathrm{CA}$ \\
\hline \multicolumn{6}{|l|}{ 01 Has a good knowledge of subject matter. } \\
\hline \multicolumn{6}{|l|}{02 Has up to date information. } \\
\hline \multicolumn{6}{|l|}{03 Is friendly towards learners. } \\
\hline \multicolumn{6}{|l|}{04 Respects learners as individuals. } \\
\hline \multicolumn{6}{|l|}{05 Understands learners well. } \\
\hline \multicolumn{6}{|l|}{06 Has the ability to manage the classroom well. } \\
\hline \multicolumn{6}{|l|}{07 Is good-tempered. } \\
\hline \multicolumn{6}{|l|}{08 Is patient. } \\
\hline \multicolumn{6}{|l|}{09 Has a sense of humour. } \\
\hline \multicolumn{6}{|l|}{10 Is aware of new teaching methods and strategies. } \\
\hline \multicolumn{6}{|l|}{11 Uses extra instructional materials such as tapes, movies, etc. } \\
\hline \multicolumn{6}{|l|}{12 Enjoys teaching. } \\
\hline \multicolumn{6}{|l|}{13 Is interested in the subject matter he/she is teaching. } \\
\hline \multicolumn{6}{|l|}{14 Has self-confidence. } \\
\hline \multicolumn{6}{|l|}{15 Has the ability to stimulate learners in learning. } \\
\hline \multicolumn{6}{|l|}{16 Knows his/her learners well (talents, abilities, weaknesses). } \\
\hline \multicolumn{6}{|l|}{17 Uses good learners to help weaker ones. } \\
\hline \multicolumn{6}{|l|}{18 Gives sufficient number of assignments. } \\
\hline \multicolumn{6}{|l|}{19 Holds adequate number of tests. } \\
\hline \multicolumn{6}{|l|}{20 Is prompt in returning test results. } \\
\hline \multicolumn{6}{|l|}{21 Is well-prepared for the class. } \\
\hline \multicolumn{6}{|l|}{22 Is careful and precise in answering learners' questions. } \\
\hline 23 Emphasizes important materials and points. & & & & & \\
\hline 24 Is a dynamic and energetic person. & & & & & \\
\hline 25 Pays attention to all students. & & & & & \\
\hline 26 Is willing to help learners in and out of the classroom. & & & & & \\
\hline 27 Encourages learners in different ways. & & & & & \\
\hline 28 Speaks clearly with a correct pronunciation. & & & & & \\
\hline 29 Has clean and tidy appearance. & & & & & \\
\hline 30 Presents materials at learners' level of comprehension. & & & & & \\
\hline 31 Enters the classroom on time. & & & & & \\
\hline 32 Leaves the classroom on time. & & & & & \\
\hline 33 Respects all ideas. & & & & & \\
\hline 34 Accepts constructive criticisms. & & & & & \\
\hline 35 Has the subject matter well-organized according to the & & & & & \\
\hline 36 Is impartial in grading. & & & & & \\
\hline 37 Has creativity in teaching. & & & & & \\
\hline 38 Involves all students in learning. & & & & & \\
\hline 39 Creates equal opportunities for learners' participation i & & & & & \\
\hline 40 Creates opportunities for discussion and asking questio & & & & & \\
\hline 41 Avoids discriminating against learners. & & & & & \\
\hline 42 Attends to the learners problems in learning. & & & & & \\
\hline $\begin{array}{l}43 \text { Divides class time appropriately for the different langu } \\
\text { purposes of the course. }\end{array}$ & & & & & \\
\hline 44 Avoids making fun of the learners. & & & & & \\
\hline 45 Avoids being too strict. & & & & & \\
\hline 46 Creates self-confidence in learners. & & & & & \\
\hline 47 Emphasizes the presence of students in the classroom. & & & & & \\
\hline
\end{tabular}

\section{APPENDIX 2}

Descriptive statistics of the answers given to 47 items comprising the CEELT Questionnaire and the rounded percentage of five points chosen by 1704 EFL learners 


\begin{tabular}{|c|c|c|c|c|c|c|c|c|}
\hline Item & Mean & SD & Missing & Completely Disagree & Disagree & Disagree omewhat & Agree & Completely Agree \\
\hline 1 & 4.40 & \begin{tabular}{|l|}
.904 \\
\end{tabular} & 1 & 1 & 1 & 11 & 27 & 60 \\
\hline 2 & 4.17 & .975 & 0 & 2 & 4 & 15 & 32 & 47 \\
\hline 3 & 3.99 & $\mid \begin{array}{l}1.218 \\
\end{array}$ & 1 & 5 & 7 & 18 & 22 & 48 \\
\hline 4 & 4.28 & 1.050 & 1 & 2 & 4 & 14 & 21 & \begin{tabular}{|l|}
59 \\
\end{tabular} \\
\hline 5 & 3.85 & 1.206 & 1 & 5 & 7 & 20 & 28 & 38 \\
\hline 6 & 4.22 & 1.085 & 1 & 3 & 4 & 12 & 26 & 54 \\
\hline 7 & 4.20 & 1.153 & 1 & 4 & 4 & 14 & 20 & 57 \\
\hline 8 & 4.10 & 1.172 & 1 & 4 & 6 & 15 & 23 & 52 \\
\hline 9 & 3.71 & 1.396 & 1 & 11 & 9 & 17 & 21 & 42 \\
\hline 10 & 3.85 & $\mid 1.193$ & 2 & 4 & 7 & 20 & 32 & 36 \\
\hline 11 & 2.72 & 1.554 & 2 & 31 & 15 & 17 & 15 & 19 \\
\hline 12 & \begin{tabular}{|l|l|}
4.24 \\
\end{tabular} & \begin{tabular}{|l}
1.007 \\
\end{tabular} & 0 & 2 & 4 & 13 & 27 & 53 \\
\hline 13 & 4.32 & \begin{tabular}{|l}
884 \\
\end{tabular} & 1 & 1 & 3 & 11 & 32 & 53 \\
\hline 14 & 4.45 & 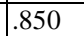 & 1 & 1 & 1 & 8 & 27 & 62 \\
\hline 15 & 3.74 & 1.276 & 1 & 7 & 9 & 19 & 28 & 36 \\
\hline 16 & 3.82 & 1.242 & 2 & 5 & 7 & 19 & 29 & 38 \\
\hline 17 & 2.93 & 1.453 & 3 & 18 & 20 & 22 & 17 & 20 \\
\hline 18 & 3.85 & $\mid 1.347$ & 2 & 7 & 8 & 16 & 22 & 45 \\
\hline 19 & 3.57 & \begin{tabular}{|l|l} 
\\
\end{tabular} & 3 & 9 & \begin{tabular}{|l|}
10 \\
\end{tabular} & 18 & 25 & 35 \\
\hline 20 & 3.69 & 1.425 & 3 & 8 & 8 & 17 & 25 & 39 \\
\hline 21 & 4.30 & 1.083 & 1 & 2 & 3 & 11 & 23 & 59 \\
\hline 22 & \begin{tabular}{|l|}
4.29 \\
\end{tabular} & 1.090 & 1 & 3 & 3 & 10 & 23 & \begin{tabular}{|l|}
59 \\
\end{tabular} \\
\hline 23 & 4.40 & \begin{tabular}{|l|l}
1.019 \\
\end{tabular} & 1 & 2 & 3 & 9 & 21 & \begin{tabular}{|l|}
64 \\
\end{tabular} \\
\hline 24 & \begin{tabular}{|l|}
4.09 \\
\end{tabular} & 1.201 & 1 & 5 & 7 & 13 & 24 & 52 \\
\hline 25 & 3.90 & 1.283 & 1 & 6 & 7 & 17 & 23 & 45 \\
\hline 26 & 3.63 & $\mid 1.317$ & 2 & 7 & 10 & 22 & 27 & 33 \\
\hline 27 & 3.31 & 1.388 & 2 & 12 & 15 & 22 & 24 & 25 \\
\hline 28 & 4.19 & 1.189 & 1 & 5 & 5 & 11 & 21 & 57 \\
\hline 29 & 4.46 & 1.003 & 1 & 2 & 2 & 8 & 17 & \begin{tabular}{|l|}
69 \\
\end{tabular} \\
\hline 30 & 4.15 & 1.112 & 1 & 3 & 3 & 13 & 30 & 49 \\
\hline 31 & 4.46 & 956 & 1 & 1 & 2 & 8 & 20 & \begin{tabular}{|l|}
67 \\
\end{tabular} \\
\hline 32 & 4.30 & $\mid 1.114$ & 1 & 4 & 4 & 8 & 22 & $\mid 61$ \\
\hline 33 & 3.98 & $\mid 1.239$ & 1 & 5 & 7 & 14 & 27 & 46 \\
\hline 34 & 3.79 & 1.327 & 2 & 7 & 8 & 17 & 27 & \begin{tabular}{|l|}
40 \\
\end{tabular} \\
\hline 35 & 4.07 & 1.173 & 2 & 3 & 5 & 15 & 27 & 48 \\
\hline 36 & 4.13 & 1.273 & 2 & 5 & 4 & 12 & 20 & \begin{tabular}{|l|}
57 \\
\end{tabular} \\
\hline 37 & 3.72 & 1.336 & 2 & 7 & 9 & 17 & 28 & 37 \\
\hline 38 & 3.99 & 1.223 & 1 & 5 & 8 & 14 & 26 & 47 \\
\hline 39 & 3.92 & 1.260 & 2 & 4 & 7 & 17 & 27 & 44 \\
\hline 40 & 4.05 & 1.254 & 2 & 5 & 6 & 14 & 22 & 52 \\
\hline 41 & 4.09 & 1.262 & 1 & 5 & 6 & 12 & 21 & 55 \\
\hline 42 & 4.02 & 1.240 & 2 & 4 & 5 & 16 & 24 & 49 \\
\hline 43 & 4.00 & \begin{tabular}{|l|l|} 
\\
\end{tabular} & 2 & 5 & 6 & 14 & 22 & 50 \\
\hline 44 & 4.22 & 1.220 & 1 & 5 & 5 & 10 & 18 & \begin{tabular}{|l|}
61 \\
\end{tabular} \\
\hline 45 & 4.08 & 1.255 & 1 & 7 & 5 & 12 & 23 & 53 \\
\hline 46 & 3.83 & \begin{tabular}{|l|l} 
& 1.307
\end{tabular} & 1 & 7 & 7 & 17 & 25 & 42 \\
\hline 47 & 4.40 & $\mid 1.046$ & 1 & 2 & 3 & 10 & 16 & \begin{tabular}{|l|}
67 \\
\end{tabular} \\
\hline
\end{tabular}

\section{APPENDIX 3}

Descriptive statistics of the answers given to 56 positive and 61 reverse (R) items comprising the EQ-I Questionnaire and the rounded percentage of five points chosen by 95 EFL teachers 


\begin{tabular}{|c|c|c|c|c|c|c|c|c|}
\hline Item & Mean & SD & Missing & Very Seldom & Seldom & Sometimes & Often & Very Often \\
\hline I001 & 4.31 & .670 & 0 & 0 & 1 & 8 & 49 & 41 \\
\hline I002R & 3.79 & .933 & 0 & 21 & 48 & 21 & 7 & 2 \\
\hline I003R & 2.39 & 1.085 & 2 & 5 & 9 & 23 & 45 & 15 \\
\hline I004 & 3.89 & .765 & 0 & 1 & 2 & 22 & 56 & 19 \\
\hline I006 & 4.45 & .649 & 0 & 0 & 1 & 5 & 41 & 53 \\
\hline I007 & 3.83 & .834 & 0 & 0 & 7 & 22 & 51 & 20 \\
\hline $\mathrm{I} 008$ & 3.94 & .885 & 0 & 1 & 6 & 17 & 49 & 26 \\
\hline I009 & 4.08 & .794 & 0 & 2 & 2 & 8 & 60 & 27 \\
\hline I010R & 3.71 & 1.030 & 0 & 23 & 41 & 21 & 13 & 2 \\
\hline I011 & 4.05 & .843 & 0 & 0 & 5 & 17 & 45 & 33 \\
\hline I013R & 3.08 & .871 & 0 & 5 & 22 & 53 & 16 & 4 \\
\hline I014R & 3.32 & 1.132 & 0 & 19 & 22 & 36 & 18 & 5 \\
\hline I015 & 4.19 & .803 & 1 & 0 & 2 & 7 & 55 & 35 \\
\hline I016 & 4.67 & .554 & 0 & 0 & 0 & 4 & 24 & 72 \\
\hline I017R & 4.18 & .945 & 0 & 47 & 31 & 15 & 7 & 0 \\
\hline I018R & 3.69 & 1.112 & 4 & 21 & 44 & 26 & 4 & 0 \\
\hline I019R & 3.06 & .836 & 0 & 5 & 20 & 53 & 20 & 2 \\
\hline I020 & 4.16 & .776 & 0 & 0 & 1 & 20 & 41 & 38 \\
\hline $\mathrm{I} 021 \mathrm{R}$ & 3.68 & .948 & 0 & 19 & 44 & 24 & 12 & 1 \\
\hline I022R & 3.68 & 1.065 & 1 & 22 & 40 & 28 & 4 & 4 \\
\hline I023R & 3.26 & 1.169 & 2 & 15 & 29 & 32 & 18 & 4 \\
\hline I024R & 3.97 & 1.134 & 1 & 42 & 27 & 20 & 7 & 2 \\
\hline I026 & 3.91 & 1.011 & 2 & 1 & 2 & 22 & 44 & 28 \\
\hline I027R & 3.66 & .941 & 0 & 17 & 46 & 25 & 9 & 2 \\
\hline I028R & 3.98 & .850 & 0 & 29 & 43 & 24 & 2 & 1 \\
\hline I029 & 3.95 & .855 & 1 & 0 & 4 & 16 & 56 & 23 \\
\hline I030R & 4.36 & .999 & 1 & 60 & 24 & 12 & 1 & 2 \\
\hline I031 & 3.92 & .781 & 0 & 2 & 1 & 19 & 59 & 19 \\
\hline I032R & 4.12 & .977 & 1 & 41 & 39 & 13 & 6 & 0 \\
\hline I033 & 3.37 & .923 & 0 & 2 & 15 & 37 & 37 & 9 \\
\hline I035R & 4.00 & .838 & 0 & 31 & 43 & 22 & 4 & 0 \\
\hline I036R & 3.79 & 1.110 & 2 & 27 & 43 & 15 & 13 & 0 \\
\hline I037 & 3.34 & 1.017 & 0 & 2 & 21 & 31 & 34 & 13 \\
\hline I038R & 3.58 & 1.135 & 0 & 21 & 40 & 21 & 12 & 6 \\
\hline I039 & 3.87 & 1.034 & 0 & 2 & 7 & 25 & 32 & 34 \\
\hline I040 & 4.38 & .760 & 0 & 0 & 2 & 11 & 35 & 53 \\
\hline I042R & 3.43 & 1.048 & 0 & 17 & 31 & 36 & 13 & 4 \\
\hline I043R & 3.56 & .754 & 0 & 8 & 45 & 41 & 4 & 1 \\
\hline I044 & 3.99 & .751 & 0 & 1 & 1 & 19 & 56 & 23 \\
\hline I045 & 4.22 & .814 & 0 & 0 & 4 & 12 & 42 & 42 \\
\hline I046R & 3.36 & 1.031 & 3 & 5 & 51 & 26 & 14 & 1 \\
\hline I047 & 4.09 & .813 & 0 & 2 & 3 & 6 & 60 & 28 \\
\hline I048R & 3.62 & 1.113 & 0 & 27 & 27 & 27 & 16 & 2 \\
\hline I049R & 2.94 & 1.050 & 0 & 5 & 26 & 35 & 24 & 9 \\
\hline I051R & 3.96 & .922 & 0 & 31 & 43 & 19 & 6 & 1 \\
\hline I052R & 3.60 & .950 & 1 & 16 & 42 & 31 & 11 & 0 \\
\hline I053R & 3.18 & .978 & 0 & 5 & 35 & 40 & 13 & 7 \\
\hline I054 & 4.61 & .607 & 0 & 0 & 0 & 6 & 26 & 67 \\
\hline I055 & 4.09 & 1.022 & 1 & 2 & 3 & 15 & 38 & 41 \\
\hline I056R & 4.11 & .928 & 0 & 41 & 35 & 19 & 4 & 1 \\
\hline I058R & 3.72 & 1.088 & 0 & 31 & 25 & 33 & 8 & 3 \\
\hline I059 & 3.87 & .925 & 1 & 1 & 3 & 23 & 47 & 24 \\
\hline I060 & 4.07 & .878 & 1 & 0 & 3 & 15 & 48 & 33 \\
\hline I061 & 4.37 & .800 & 0 & 0 & 3 & 11 & 33 & 54 \\
\hline I062 & 4.19 & .719 & 0 & 0 & 2 & 12 & 52 & 35 \\
\hline I063 & 4.12 & .616 & 0 & 0 & 2 & 7 & 67 & 23 \\
\hline I064R & 3.29 & .977 & 0 & 9 & 33 & 41 & 12 & 5 \\
\hline I066R & 4.05 & .927 & 0 & 37 & 40 & 15 & 8 & 0 \\
\hline I067 & 3.54 & 1.009 & 2 & 1 & 7 & 35 & 40 & 15 \\
\hline I068R & 3.68 & 1.034 & 1 & 22 & 40 & 25 & 11 & 1 \\
\hline I069 & 3.76 & .953 & 1 & 2 & 4 & 24 & 49 & 19 \\
\hline I070R & 3.88 & 1.175 & 2 & 37 & 34 & 16 & 11 & 1 \\
\hline I072 & 2.79 & .999 & 1 & 6 & 35 & 31 & 25 & 2 \\
\hline I073R & 3.41 & 1.067 & 0 & 14 & 38 & 31 & 12 & 6 \\
\hline I074 & 3.41 & .819 & 0 & 2 & 7 & 45 & 38 & 7 \\
\hline I075R & 3.58 & .963 & 0 & 17 & 39 & 32 & 11 & 2 \\
\hline I076R & 3.76 & .884 & 0 & 21 & 42 & 28 & 8 & 0 \\
\hline I077R & 4.03 & 1.015 & 0 & 42 & 27 & 24 & 4 & 2 \\
\hline I078 & 3.64 & .811 & 0 & 0 & 8 & 32 & 47 & 13 \\
\hline I080 & 3.81 & .842 & 0 & 1 & 5 & 24 & 51 & 19 \\
\hline I081 & 4.32 & .937 & 2 & 0 & 0 & 12 & 35 & 52 \\
\hline
\end{tabular}




\begin{tabular}{|c|c|c|c|c|c|c|c|c|}
\hline I082R & 3.03 & $\mid 1.096$ & 1 & 11 & 25 & 24 & 38 & 1 \\
\hline I083R & 3.69 & 1.053 & 0 & 22 & 43 & 21 & 9 & 4 \\
\hline I084 & 3.92 & .871 & 0 & 2 & 3 & 20 & 51 & 24 \\
\hline $\mathrm{I} 085$ & 4.00 & \begin{tabular}{|l|}
.887 \\
\end{tabular} & 0 & 3 & 1 & 17 & 51 & 28 \\
\hline I086R & 3.47 & .977 & 0 & 16 & 33 & 37 & 13 & 2 \\
\hline I087R & 3.24 & .964 & 1 & 8 & 32 & 39 & 19 & 1 \\
\hline I088 & 4.11 & .856 & 1 & 0 & 3 & 12 & 52 & 33 \\
\hline I089 & 4.00 & .957 & 2 & 0 & 3 & 15 & 51 & 29 \\
\hline $\mathrm{I} 090$ & 4.57 & .781 & 1 & 1 & 0 & 1 & 32 & 65 \\
\hline I091R & 3.89 & 1.086 & 1 & 34 & 37 & 19 & 7 & 2 \\
\hline I092R & 3.53 & .944 & 0 & 17 & 34 & 35 & 15 & 0 \\
\hline I093R & 2.94 & 1.128 & 2 & 11 & 16 & 41 & 24 & 6 \\
\hline I095 & 4.55 & .726 & 0 & 2 & 0 & 1 & 35 & 62 \\
\hline I096 & 3.87 & .789 & 0 & 0 & 4 & 25 & 49 & 21 \\
\hline I097R & 3.55 & .931 & 0 & 14 & 42 & 32 & 11 & 2 \\
\hline I098 & 3.93 & .902 & 1 & 0 & 4 & 21 & 47 & 26 \\
\hline I099 & 4.32 & .570 & 0 & 0 & 0 & 5 & 58 & 37 \\
\hline I100 & 4.15 & .863 & 0 & 1 & 4 & 12 & 45 & 38 \\
\hline I102R & 3.54 & 1.080 & 1 & 18 & 38 & 31 & 8 & 4 \\
\hline I103R & 3.40 & .916 & 1 & 9 & 37 & 41 & 11 & 1 \\
\hline I104 & 4.26 & .775 & 0 & 0 & 1 & 17 & 37 & 45 \\
\hline I105 & 4.14 & .906 & 0 & 3 & 1 & 13 & 45 & 38 \\
\hline I106 & 3.97 & .994 & 1 & 2 & 3 & 18 & 44 & 32 \\
\hline I107R & 3.98 & .956 & 1 & 31 & 46 & 17 & 4 & 1 \\
\hline I108 & 4.24 & .680 & 0 & 0 & 0 & 14 & 48 & 38 \\
\hline I110R & 2.81 & 1.065 & 1 & 5 & 23 & 27 & 37 & 6 \\
\hline I111R & 3.89 & 1.005 & 0 & 35 & 29 & 27 & 7 & 1 \\
\hline I112 & 3.92 & 1.069 & 2 & 1 & 5 & 18 & 42 & 32 \\
\hline I113 & 4.20 & .807 & 0 & 0 & 3 & 15 & 41 & 41 \\
\hline I114 & 3.97 & .831 & 0 & 0 & 6 & 17 & 51 & 26 \\
\hline I116R & 3.52 & 1.080 & 1 & 19 & 34 & 33 & 11 & 3 \\
\hline I117R & 3.74 & .902 & 1 & 19 & 43 & 34 & 2 & 1 \\
\hline I118 & 4.12 & .886 & 1 & 0 & 1 & 20 & 40 & 38 \\
\hline I119 & 4.48 & .784 & 1 & 0 & 1 & 4 & 35 & 59 \\
\hline I120 & 4.20 & .766 & 0 & 0 & 2 & 15 & 44 & 39 \\
\hline I121R & 3.56 & 1.039 & 0 & 19 & 35 & 35 & 6 & 5 \\
\hline I122R & 3.71 & .988 & 0 & 22 & 39 & 29 & 6 & 3 \\
\hline I124 & 4.57 & .679 & 0 & 1 & 1 & 1 & 34 & 63 \\
\hline I125R & 3.93 & .937 & 1 & 28 & 44 & 21 & 5 & 0 \\
\hline I126R & 3.43 & 1.068 & 0 & 17 & 33 & 32 & 15 & 4 \\
\hline I127R & 3.83 & .871 & 0 & 21 & 48 & 25 & 3 & 2 \\
\hline I128R & 3.74 & 1.084 & 1 & 25 & 41 & 20 & 11 & 2 \\
\hline I129 & 4.05 & 1.004 & 2 & 1 & 1 & 17 & 43 & 36 \\
\hline I130R & 3.53 & .955 & 0 & 14 & 41 & 33 & 9 & 3 \\
\hline I131R & 3.47 & 1.287 & 5 & 18 & 44 & 19 & 11 & 3 \\
\hline I132R & 3.73 & 1.036 & 1 & 25 & 36 & 28 & 8 & 1 \\
\hline
\end{tabular}

\section{REFERENCES}

[1] Bar-On, R. (1997). The Emotional Quotient Inventory (EQ-i): a test of emotional intelligence. Toronto: Multi-Health Systems.

[2] Bar-On, R. (2002). EQ-i Group Report: SAMPLE 001. North Tonawanda, NY: Multi-Health Systems.

[3] Bar-On, R. (2003). EQ-i 125 Resource Report: Samantha Wright. North Tonawanda, NY: Multi-Health Systems.

[4] Bar-On, R., Tranel, D., Denburg, N. L., \& Bechara, A. (2003). Exploring the neurological substrate of emotional and social intelligence. Brain, 126, 1790-1800. DOI: 10.1093/brain/awg177.

[5] Batool, S. S. (2009). Development and validation of emotional intelligence scale and emotional intelligence as a predictor of marital quality. Unpublished PhD thesis, University of the Punjab, Lahore, Pakistan.

[6] Batool, S. S., \& Khalid, R. (2011). Development of Indigenous Scale of Emotional Intelligence and Evaluation of Its Psychometric Properties. Pakistan Journal of Social and Clinical Psychology, 9, 66-72.

[7] Birjandi, P., \& Bagherkazemi, M. (2010). The Relationship between Iranian EFL Teachers' Critical Thinking Ability and their Professional Success. English Language Teaching, 3(2), 135-145.

[8] Brachett, M., \& Salovey, P. (2006). Measuring emotional intelligence with the Meyer-Salovey-Caruso Emotional Intelligence Test (MSCEIT). Psicothema, 18, Supl., 34-41.

[9] Butler, C. J., \& Chinowsky, P. S. (2006). Emotional intelligence and leadership behavior in construction executives. Journal of Management in Engineering, 22(3), 119-125. DOI: 10.1061/(ASCE)0742-597X(2006)22:3(119).

[10] Caruso, D. R. \& Salovey, P. (2004). The emotionally intelligent manager: how to develop and use the four key emotional skills of leadership. San Francisco, CA: Jossey-Bass.

[11] Derksen, J., Kramer, I., \& Datzko, M. (2002). Does a self-report measure for emotional intelligence assess something different than general intelligence? Personality and Individual Differences, 32, 37-48. 
[12] Eysenck, H. J. (1975). The measurement of emotion: Psychological parameters and methods. In L. Levi (Ed.), Emotions: their parameters and measurement. New York: Raven Press.

[13] Fahim, M., Pishghadam, R. (2007). On the role of emotional, psychometric, and verbal intelligences in the academic achievement of university students majoring in English language. Asian EFL journal, 9(4), 240-253.

[14] Feldman-Barret, L., \& Salovey, P. (Eds.) (2002). The wisdom in feeling: psychological processes in emotional intelligence. New York: Guilford Press.

[15] Fernandez-Berrocal, P., \& Extremera, N. (2006). Emotional intelligence: A theoretical and empirical review of its first 15 years of history. Psicothema, 18(supl.), 7-12.

[16] Ghanizadeh, A., \& Moafian, F. (2009). The role of EFL teachers' emotional intelligence in their success. ELT Journal Advance Access, 1-12. doi:10.1093/elt/ccp084.

[17] Hemmati, T., Mills, J. F., \& Kroner, D. G. (2004). The validity of the Bar-On emotional intelligence quotient in an offender population. Personality and Individual Differences, 37, 695-706.

[18] Khodadady, E. (2010). Factors Underlying Characteristics of English Language Teachers: Validity and Sample Effect. Iranian Journal of Applied Linguistics (IJAL), 13(2), 47-74.

[19] Khodadady, E., \& Mirjalili, P. (2012). Exploring the relationship between English teachers' effectiveness and their personality. Continental J. Education Research, 5 (1), $1-11$.

[20] Mayer, J. D., \& Salovey, P. (1997). What is emotional intelligence? In P. Salovey \& D. J. Sluyter (Eds.), Emotional development and emotional intelligence: Educational implications (pp. 3-31). New York: Basic Books.

[21] Mayer, J. D., Salovey, P., Caruso, D. R., \& Sitarenios, G (2001). Emotional intelligence as a standard intelligence. Emotion, I, 232-242.

[22] Mayer, J. D., Salovey, P., Caruso, D. R., \& Sitarenios, G (2003). Measuring emotional intelligence with the MSCEIT Version 2.0. Emotion, 3, 97-105.

[23] Mayer, J., D., Salovey, P., \& Caruso, D. (2002). Mayer-Salovey-Caruso Emotional Intelligence Test (MSCEIT), Version 2.0. Toronto: Multi-Health Systems.

[24] Moafian, F., \& Pishghadam, R. (2008). Construct validation of a questionnaire on characteristics of successful English language teachers. Pazhuhesh-e Zabanheye Khareji Journal (University of Tehran), 54, 127-142.

[25] Suwandee, A. (1995). Students' perceptions of university instructors' effective teaching characteristics. SLLT Journal, 5, 6-22.

[26] Van Rooy, D. L., \& Viswesvaran, C. (2004). Emotional intelligence: A meta-analytic investigation of predictive validity and nomological net. Journal of Vocational Behavior, 65, 71-95.

[27] Yule, G. (2006). The study of language ( $3^{\text {rd }}$ ed.). Cambridge: CUP.

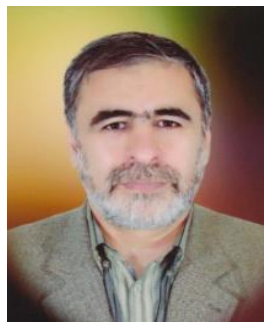

Ebrahim Khodadady was born in Iran in 1958. He obtained his PhD in Applied Linguistics from the University of Western Australia in 1998. He holds TESL Ontario and Canadian Language Benchmarks Placement Test (CLPBPT) certificates and has taught English as a first, second and foreign language to high school and university students in Australia, Canada and Iran.

$\mathrm{He}$ is currently an academic member of English Language and Literature Department at Ferdowsi University of Mashhad, Iran. He was invited as a VIP by Brock University in Canada in 2004 and served as the Associate Director of Assessment Center at George Brown College in Toronto for almost a year. His published books are Multiple-Choice Items in Testing: Practice and Theory (Tehran, Rahnama, 1999), Reading Media Texts: Iran-America Relations (Sanandaj, Kurdistan University, 1999) and English Language Proficiency Course: First Steps (Sanandaj, Kurdistan University, 2001). His main research interests are Testing, Language Learning and Teaching.

Dr. Khodadady is currently a member of TESL Ontario and European Society for Translation Studies. He is on the editorial board of Ferdowsi Review: An Iranian Journal of TESL, Literature and Translation Studies and has reviewed some research papers for Iranian Journal of Applied Linguistics and TESL Canada Journal as a guest reviewer. 